Discussion

Papers

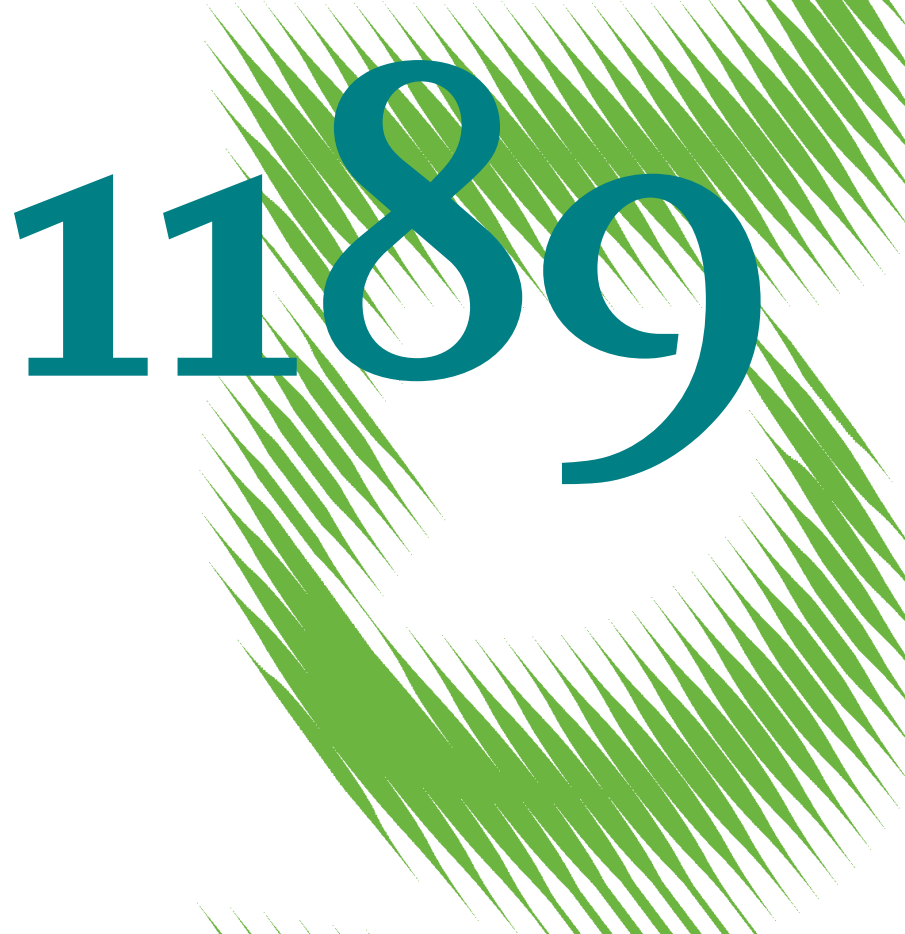

Responsive Adjustment of Feed-in Tariffs to Dynamic PV Technology Development 
Opinions expressed in this paper are those of the author(s) and do not necessarily reflect views of the institute.

IMPRESSUM

(C) DIW Berlin, 2012

DIW Berlin

German Institute for Economic Research

Mohrenstr. 58

10117 Berlin

Tel. $+49(30) 89789-0$

Fax +49 (30) $89789-200$

http://www.diw.de

ISSN print edition $1433-0210$

ISSN electronic edition 1619-4535

Papers can be downloaded free of charge from the DIW Berlin website:

http://www.diw.de/discussionpapers

Discussion Papers of DIW Berlin are indexed in RePEc and SSRN:

http://ideas.repec.org/s/diw/diwwpp.html

http://www.ssrn.com/link/DIW-Berlin-German-Inst-Econ-Res.html 


\title{
Responsive adjustment of feed-in tariffs to dynamic PV technology development
}

\section{Thilo Grau*}

February 14, 2012

\begin{abstract}
This paper reviews the adjustments of the feed-in tariff for new solar photovoltaics (PV) installations in Germany. As PV system prices declined rapidly over the last years, the German government implemented automatic mechanisms to adjust the support level for new installations in response to deployment volumes. This paper develops an analytic model to simulate weekly installations of PV systems $\leq 30 \mathrm{~kW}$ (35\% market share in 2010 ) based on project profitability and duration. The model accurately replicates observed market developments, showing the need for (i) more frequent tariff reductions (ii) and an appropriate choice of adjustment response parameters. The model can be used to test for appropriate parameter choices, and to compare different policy designs. To illustrate this, the competing proposals that had been discussed in 2011 are simulated. A robust choice must perform well against multiple scenarios for future PV system prices. The analysis shows that adjustment schemes with more frequent tariff reductions would have reached deployment targets in 2011 more effectively.
\end{abstract}

JEL Classification: O30, O31, Q42, Q48

Keywords: feed-in tariff, photovoltaic, renewable deployment

\footnotetext{
* German Institute for Economic Research (DIW Berlin), and Climate Policy Initiative (thilo.grau@cpiberlin.org). I am grateful to Karsten Neuhoff and Frieder Borggrefe for guidance in approaching this paper. I thank Anna Bergek, Rodney Boyd, Jochen Diekmann, Wenjuan Dong, Volker Hoffmann, Jörn Hoppmann, Carsten Pfeiffer, Mario Ragwitz, Margaret Taylor, Jim Watson and Ingrid Weyher for their helpful comments and suggestions. I also benefited from the comments of participants at the ETH Zurich PhD Academy on Sustainability and Technology in 2012. Comments to this discussion paper are welcome.
} 



\section{Introduction}

Feed-in tariff schemes have been implemented by more than 60 countries and are therefore the most common policy instrument to support renewable energy sources (REN21 2011). The guaranteed off-take price facilitates low-cost financing and administrative procedures. Are feed-in tariffs also compatible with the policy objectives formulated as investment volumes in (specific) renewable technologies? The German National Renewable Energy Action Plan (NREAP) defines a deployment target of $52 \mathrm{GW}$ installed photovoltaics (PV) capacity for 2020, with 3.5 GW annual PV deployment.

This paper reviews the experience with the adjustments of the German PV feed-in tariff within the Renewable Energy Sources Act (Erneuerbare-Energien-Gesetz, EEG), so as to deliver the annual deployment target level in the presence of dynamic PV system price developments. Feed-in tariff levels and degression rates were revisited every four years until 2009. In recent years, deployment volumes significantly exceeded target volumes, turning Germany into the largest PV market in 2009 and 2010 (accounting for $43 \%$ of global cumulative PV installations in 2010). This is seen as a challenge, as the higher volumes increase the policy costs borne by electricity consumers. Therefore, an automatic adjustment mechanism dependent on ongoing deployment volumes was introduced in 2009 in order to match PV system price reductions, followed by further adjustments to the mechanism in 2010 and 2011. Nevertheless, the deployment volume again reached 7.5 GW of new PV capacity in 2011 (see Figure 1.1).

Figure 1.1: Annual PV installations in Germany 2000-2010, with targets until 2020

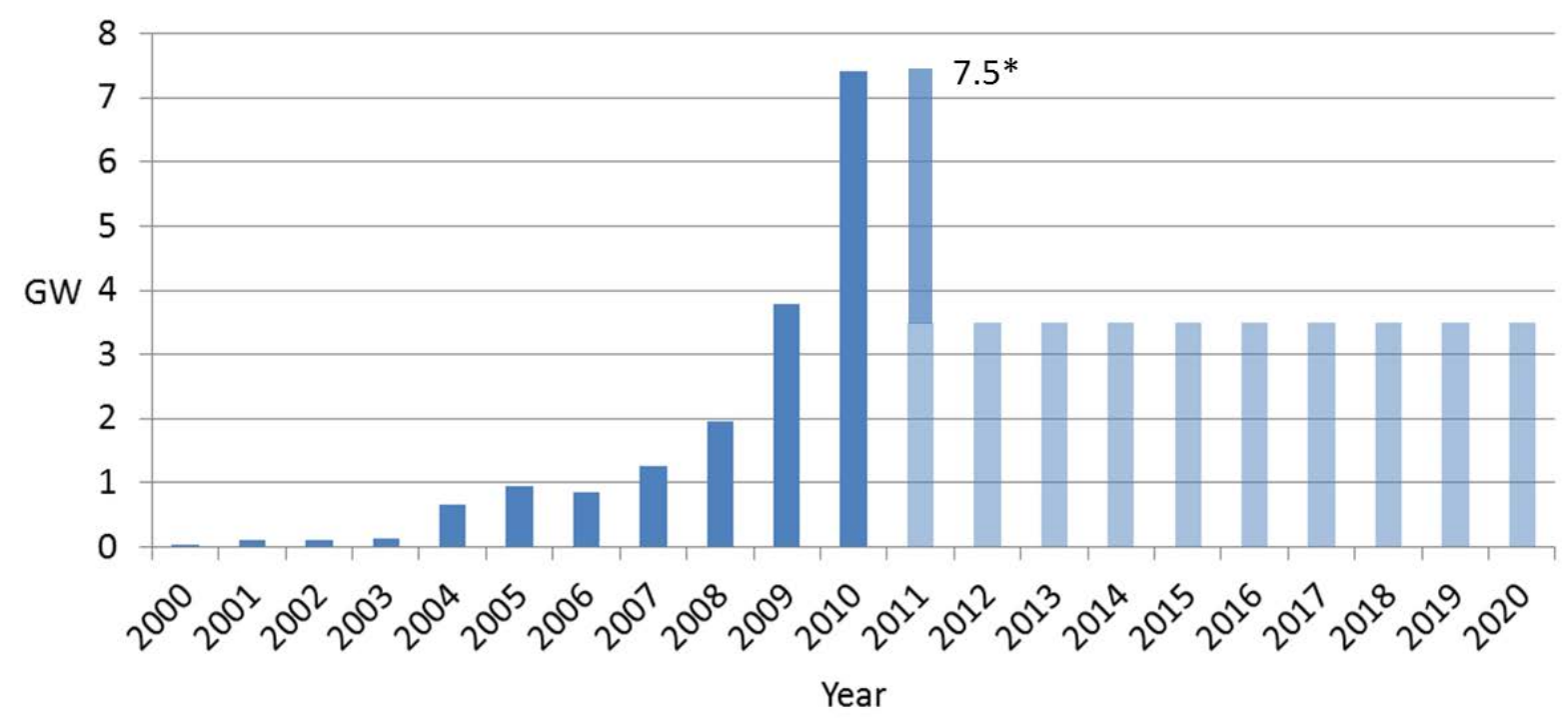

Sources: Data from BMU (2011) and German National Renewable Energy Action Plan. *Forecast Bundesnetzagentur. 
This paper combines a characterization of the observed market developments with an analytic framework that allows for the disentanglement of the various drivers of the development.

The analytic model introduced in this paper simulates the evolution of new PV installations and feed-in tariffs for systems $\leq 30 \mathrm{~kW}$ on the basis of observed PV prices. This simple model is based on only three factors: (i) deployment increases proportionately with project profitability, (ii) profit expectations of investors decrease every year, and (iii) in periods prior to feed-in tariff reductions, projects are implemented faster in order to still receive the higher subsidy. Moreover, the model can be used to test different policy design proposals.

The experience of the last years shows that the deployment volumes can be explained by simple factors. This allows for testing of individual adjustment proposals. Model results show that the adjustment frequency of the feed-in tariff has to be increased to better correspond to the short project durations of small-scale systems. Moreover, policy proposals need to be tested against different price scenarios.

Thereby, the PV feed-in tariff adjustment steps can be defined systematically.

In the following, Section 2 traces the historic evolution of PV system prices and support level adjustments in Germany, and shows the responsiveness of PV deployment to feed-in tariff levels. Section 3 provides an analytic framework to explain the drivers for the observed behavior. Section 4 illustrates how this framework can be used to assess different policy design options. Section 5 concludes the paper with a recap of findings.

\section{PV technology development and feed-in tariff adjustment}

\subsection{Historic evolution of PV system prices}

In recent years, prices of PV systems have undergone a surprisingly rapid reduction. Figure 2.1 shows that prices for rooftop systems up to 100 kWp decreased by 58\% in Germany between Q2 2006 and Q4 2011. 
Figure 2.1: Average customer prices for installed rooftop PV systems up to $100 \mathrm{kWp}$

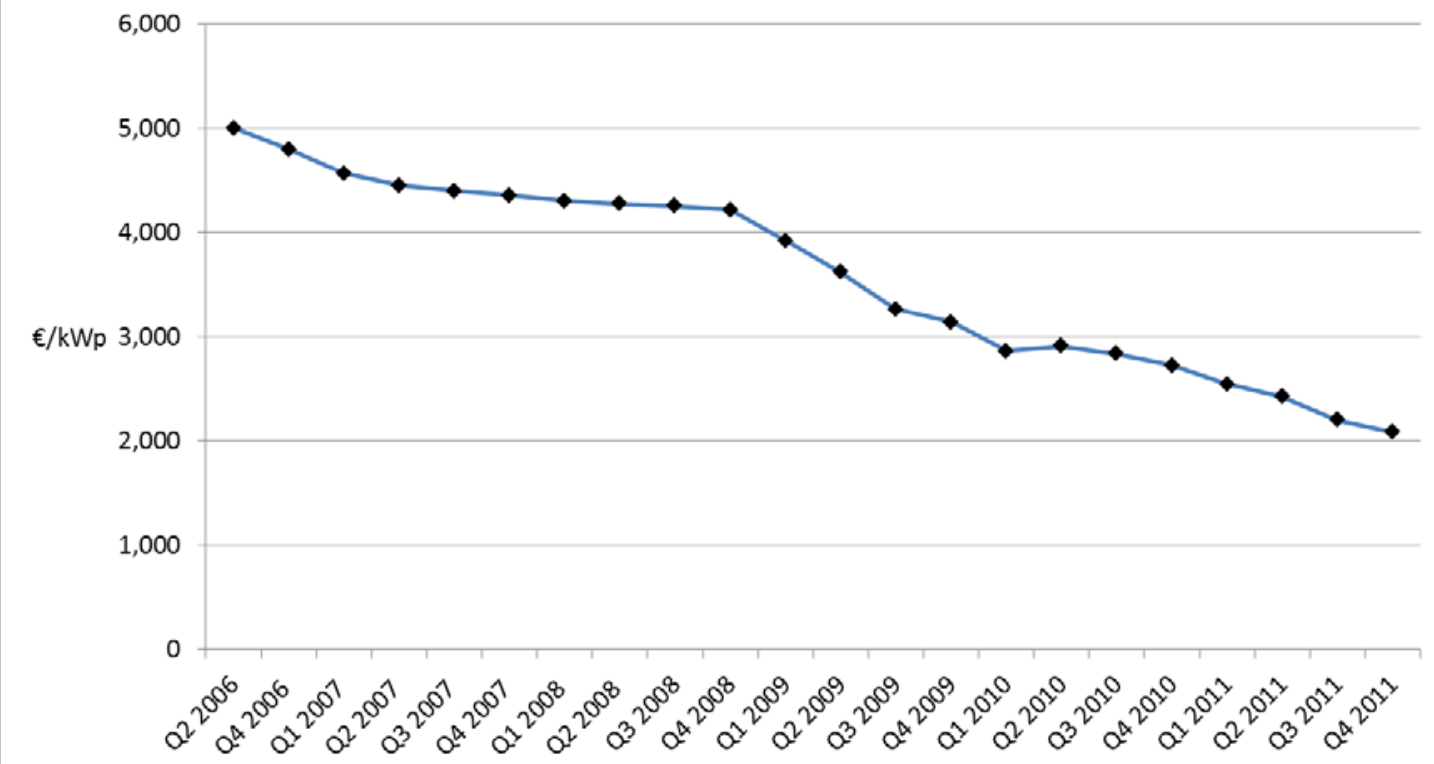

Data sources: BSW-Solar (2011) and BSW-Solar Preisindex Photovoltaik (2012). Prices shown are without value added tax.

\subsection{History of PV feed-in tariff adjustments in Germany}

The Renewable Energy Sources Act (EEG) was established in 2000 to foster deployment of renewable energy technologies in Germany and to thus support a stable market for manufacturing companies. Technology-specific feed-in tariffs offer economic incentives to support renewable power generation, and are usually guaranteed for a period of 20 years. The tariff levels for new installation were traditionally reduced by annual degression rates and reviewed every four years, thus creating the incentive for manufacturers to improve technologies and to pass cost reductions on to consumers.

Anticipating photovoltaic system prices has however become increasingly challenging in light of their dynamic cost developments. If the degression rate is set above the innovation potential, feed-in tariffs may become too low to allow for an economic deployment of further renewable technologies. Given the share of the German market in the global situation, this was interpreted as a high risk for the further development of the technology and the industry. Setting degression rates too low can lead to windfall gains for manufacturers or project developers, and deployment volumes that exceed initial plans can cause significant cost increases.

The first PV feed-in tariff was established at a rate of $0.99 \mathrm{DM} / \mathrm{kWh}$ (around $0.51 € / \mathrm{kWh}$ ), and annual degression rates were set at $5 \%$ for all systems. From 2004 onwards, feed-in tariffs were graded according to system capacity and installation types (rooftop, façade, and field installations), with rates between 0.46 and $0.62 € / \mathrm{kWh}$. Annual degression rates remained constant at $5 \%$, and increased to $6.5 \%$ for field installations from 2006 onwards. Since 2009, there are four categories for rooftop installations ( $\leq 30 \mathrm{~kW}, 30-100 \mathrm{~kW}, 100-1000 \mathrm{~kW},>1000 \mathrm{~kW})$. 
With the amendment of the EEG in 2009, a "growth corridor" was introduced for PV, to allow the tariff level for new installations to respond to deployment volumes on an annual basis. The EEG 2009 envisaged a yearly $8-10 \%$ degression rate of these tariffs, which would change according to the amount of newly installed PV capacity each year. However, as PV system prices declined in 2009 much more rapidly than originally expected, deployment increased strongly, and therefore additional reductions of 8-13\% and 3\% were implemented on 1 July 2010 and 1 October 2010 respectively.

The new corridor degression system implemented in 2010 projected a baseline of $3.5 \mathrm{GW}$ annual installations. The basic degression rate of $9 \%$ would increase by up to $4 \%$, depending on the deployment above this baseline. As PV installations amounted to $7.4 \mathrm{GW}$ in 2010, feed-in tariffs were reduced by $13 \%$ in January 2011.

In 2011, the following PV feed-in tariff adjustment mechanism was implemented by the German government:

- On 1 July 2011 the feed-in tariff would be reduced by 3\% if between March and May 2011 on a yearly projected basis more than $3.5 \mathrm{GW}$ solar panels had been installed. ${ }^{1}$ For each additional $\mathrm{GW}$ above this value up to $7.5 \mathrm{GW}$ the tariff would be reduced by another $3 \%$, up to a maximum of $15 \%$.

- On 1 January 2012 the basic yearly 9\% degression rate would increase by $3 \%$ if between October 2010 and September 2011 more than 3.5 GW had been installed, and by another 3\% for each additional GW above this value up to $7.5 \mathrm{GW}$. The percentage would decrease by $2.5 \%$ if between October 2010 and September 2011 less than $2.5 \mathrm{GW}$ had been installed, and by another $2.5 \%$ for each additional $500 \mathrm{MW}$ below this value down to $1.5 \mathrm{GW}$. This means that the possible yearly degression rate could be between $1.5 \%$ and $24 \%$.

- In determining the new degression rate on 1 January 2012, the advanced "interim" degression from 1 July 2011 would be taken into account. For instance, if $6 \mathrm{GW}$ were installed between October 2010 and September 2011, this would mean a yearly degression rate of 18\%. If on 1 July 2011 there had already been an "interim" degression of 15\%, the degression rate on 1 January 2012 would therefore have been $3.53 \%{ }^{2}$

This mechanism led to a 0\% degression rate in July and September 2011 (as less than 875 MW was installed between March and May 2011), and to a 15\% degression rate at the beginning of 2012 (as 5.2 GW were installed between October 2010 and September 2011). According to the Bundesnetzagentur (2012), a new monthly record of $3 \mathrm{GW}$ was installed in Germany in December 2011. Therefore, shortly after the newly amended EEG (2012) came into force on 1 January 2012, German Environment Minister Norbert Röttgen announced on 19 January 2012 that PV feed-in tariffs will be assessed on a monthly or at least quarterly basis in the future.

\footnotetext{
${ }^{1}$ The adjustment would be made on 1 July 2011 for rooftop systems, and on 1 September 2011 for groundmounted systems.

${ }^{2}$ See Reichmuth (2011) (pages 220-221).
} 


\subsection{Weekly PV deployment and market responsiveness}

To improve monitoring of market development, new PV systems must be registered at the Federal Network Agency (Bundesnetzagentur) since January 2009. Although these systems are categorized according to their date of registration, and not their date of commissioning, the data allows for a realistic assessment of actual market volume, according to Reichmuth (2011, page 8).

Figure 2.2 shows weekly PV installations and feed-in tariff levels in Germany since January 2009. In periods prior to a reduction of the feed-in tariff, the volume of PV installations increased as house owners and project developers still wanted to profit from the higher subsidies. While Reichmuth (2011, page 211) states that the degression in October 2010 had no comparable impact (on a monthly basis), our weekly data analysis also shows a demand peak in the last week of September 2010.

Figure 2.2: Weekly PV installations and feed-in tariff levels in Germany between January 2009 and May 2011

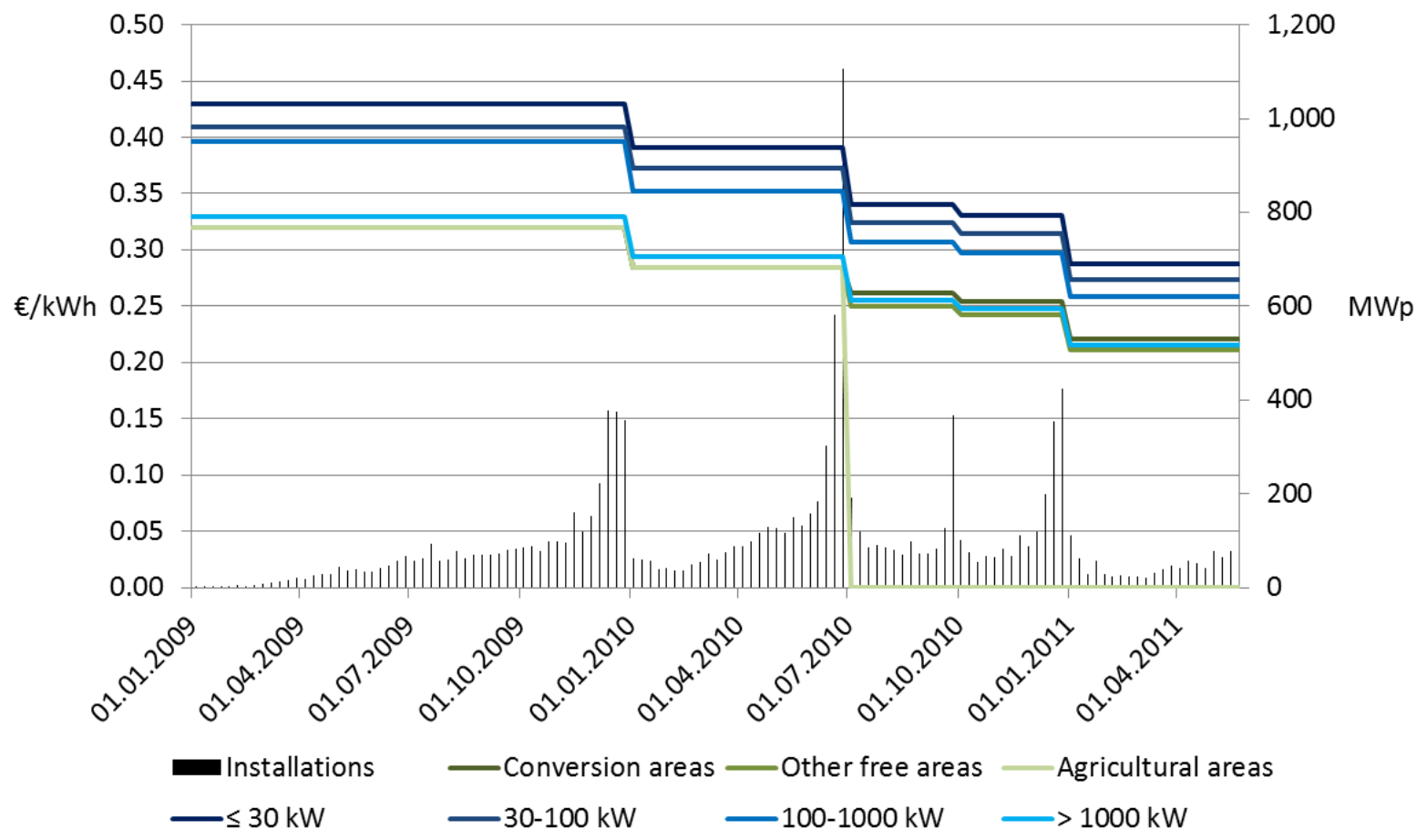

Installations based on data from Bundesnetzagentur.

These characteristic demand peaks can be observed in all relevant sub-categories, as shown in Figure 2.3. However, market responsiveness of these categories varies. Larger projects are usually more responsive to changing support schemes, if we compare PV deployment within the last week (or the last two weeks) before a feed-in tariff reduction to cumulative installations within the whole period of the same feed-in tariff levels. For instance, PV deployment was three times higher within the last two weeks of 2009 than the annual average for systems $\leq 30 \mathrm{~kW}$, five times higher for systems between 30 and 100 
kW, eight times higher for systems between 100 and $1000 \mathrm{~kW}$, and seven times higher for installations above $1 \mathrm{MW}$.

Figure 2.3: Weekly PV installations for relevant size categories in Germany between January 2009 and May 2011

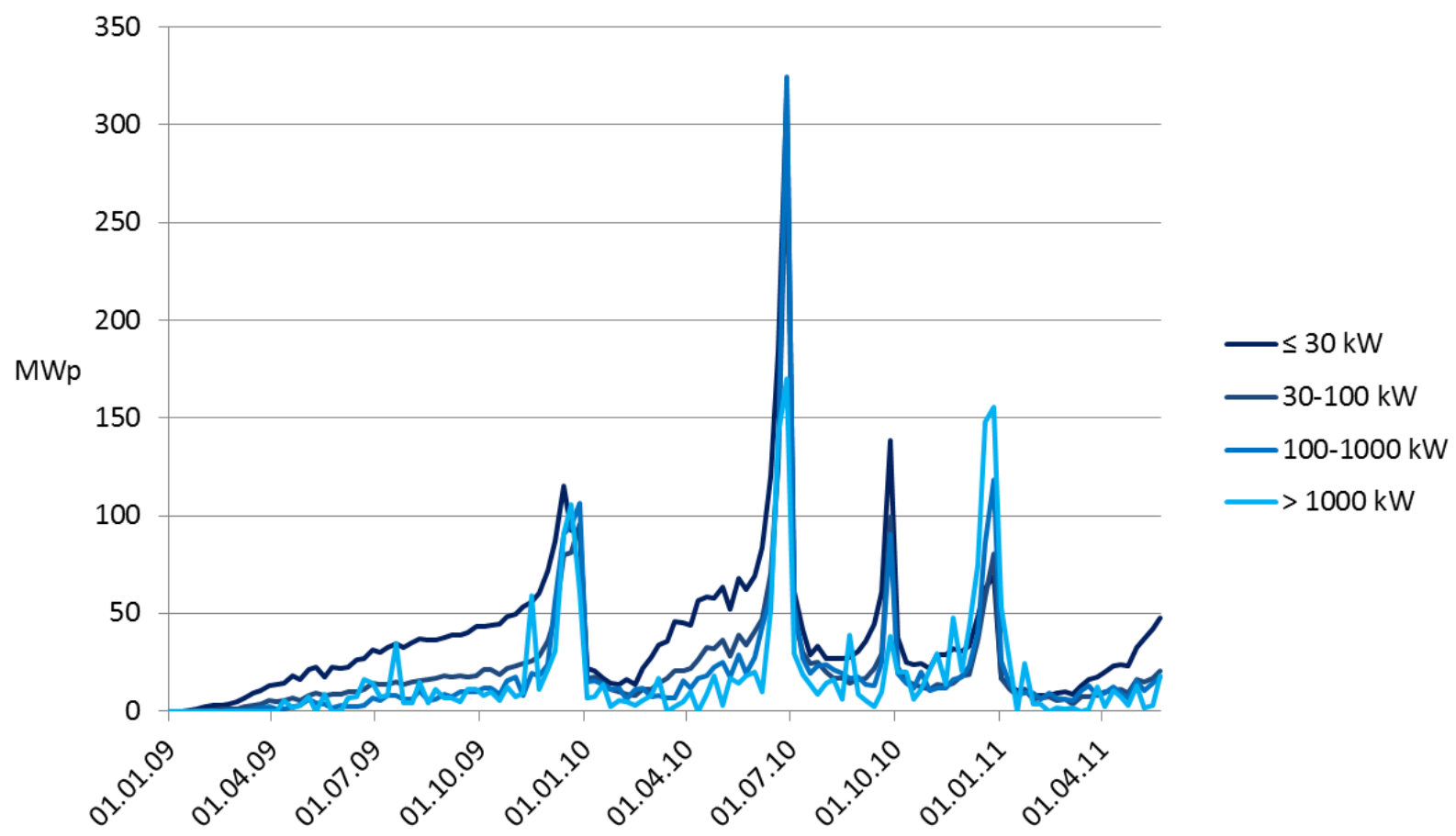

Based on data from the Bundesnetzagentur.

This work focuses on the small-scale rooftop category of the German PV feed-in tariff, as rooftop PV installations $\leq 30 \mathrm{~kW}$ accounted for $44 \%$ and 35\% of total installations in Germany in 2009 and 2010 respectively. Weekly deployment of PV systems $\leq 30 \mathrm{~kW}$ is shown by the dark curve in Figure 2.3.

\section{Analytic framework}

The deployment effectiveness of a feed-in tariff scheme is analyzed using a simple model. The model depicts three factors impacting deployment:

(i) Deployment increases proportionately with project profitability.

(ii) Profit expectations of investors decrease every year.

(iii) Deployment is responsive to feed-in tariff changes: In periods prior to a feed-in tariff reduction, project implementation accelerates to still receive the higher tariff levels. 


\subsection{Basic model}

The basic model (without simulation of demand peaks) is as follows. We consider a discrete-time economy. At the beginning of every period $t$, each household decides whether to invest in a PV project, that would be finalized at date $t+d$, taking into account the average project duration $d$. PV installations $Y_{t+d}$ at time $t+d$ depend on profits $\pi_{t+d}$ according to the function

$$
Y_{t+d}=\alpha * \pi_{t+d}-c
$$

with parameters $\alpha$ and $c$. To account for increasing interest and changing profit expectations of households over time, both parameters $\alpha$ and $c$ are determined on a yearly basis.

Profits of PV projects are defined as net present value:

$$
\pi_{t+d}=v_{t+d}-p_{t}
$$

where $p_{t}$ is the average system price at date $t$ and $v_{t+d}$ is the present value of the feed-in tariff at time $t+d$.

The present value $v_{t}$ of the feed-in tariff is given by the equation:

$$
v_{t}=f_{t} * h * \sum_{j=0}^{n}(1+i)^{-j},
$$

where $f_{t}$ is the feed-in tariff at date $t, h$ is the amount of full load hours per annum, $n$ is the amount of years which the feed-in tariff is paid for, and $i$ is the annual interest rate.

\subsection{Advanced model with peak simulation}

To account for the characteristic demand peaks of historic PV market evolution (see Figure 2.3), the basic model is extended as follows. We assume that, in periods before the feed-in tariff is reduced, investors make use of the flexibility to accelerate project execution so as to still qualify for the higher tariff levels. This market behavior then leads to the observed "clearance sale" effects. The representative investor choses the project duration $d_{t}$ at time $t$ according to the function

$$
\begin{gathered}
d_{t}=\max l \\
\text { subject to } \pi_{t+l} \geq \pi_{t+d_{\text {ave }}} \\
d_{\min } \leq l \leq d_{\text {ave }}
\end{gathered}
$$

where $d_{\min }$ and $d_{\text {ave }}$ are the minimum and average project duration respectively. While projects are usually implemented within the average duration, implementation is accelerated in periods prior to feed-in tariff reductions.

Thus, the volume of PV installations at date $t+d_{a v e}$ is given by the equation:

$$
Y_{t+d_{\text {ave }}}=\sum_{\substack{-\infty \leq m \leq \infty \\ \text { if }\left(m+d_{t+m}=d_{\text {ave }}\right)}}\left(\alpha \pi_{t+d_{\text {ave }}}-c\right)
$$




\section{Quantitative evaluation}

\subsection{Parameter choices}

For the purpose of our model, we take a period $t$ to correspond to one week. We consider that PV modules can achieve around 900 full load hours per year on average in Germany, and that the feed-in tariff is paid for a time period of $n=20$ years. We furthermore assume an annual interest rate of $i=4.5 \%$.

The overall process duration of PV projects depends on system sizes. In Germany, according to the PV LEGAL $^{3}$ project, it varies between 3 to 8 weeks ( 6 weeks on average) for small-scale installations on residential buildings, 6 to 24 weeks ( 12 weeks on average) for small to medium-scale installations on commercial buildings, and 53 to 132 weeks ( 85 weeks on average) for medium to large-scale groundmounted installations on open lands. To calculate profits of small-scale rooftop systems, we use their average project duration of 6 weeks.

The analytic framework is based on data that was available in summer 2011. We use quarterly PV system price data (Q4 2008 - Q2 2011) from BSW-Solar (2011) for installations $\leq 100 \mathrm{~kW}$. We assume it reflects the price within the middle of each quarter and linearly approximate the weekly price date for the intermediary weeks. ${ }^{4}$ We adjust the data that is reported for all installations $\leq 100 \mathrm{~kW}$ to systems $\leq$ $30 \mathrm{~kW}$ with a fixed shift factor. This shift factor is calculated from monthly system price data (0-10 kW and 10-30 kW, June 2009 - May 2011) from [Photon] and based on installation data (2009-2010) from Reichmuth (2011, Figure 1-4).

Figure 4.1: PV feed-in tariff, system prices, and profits for solar panels $\leq 30 \mathrm{~kW}$ in Germany between January 2009 and May 2011

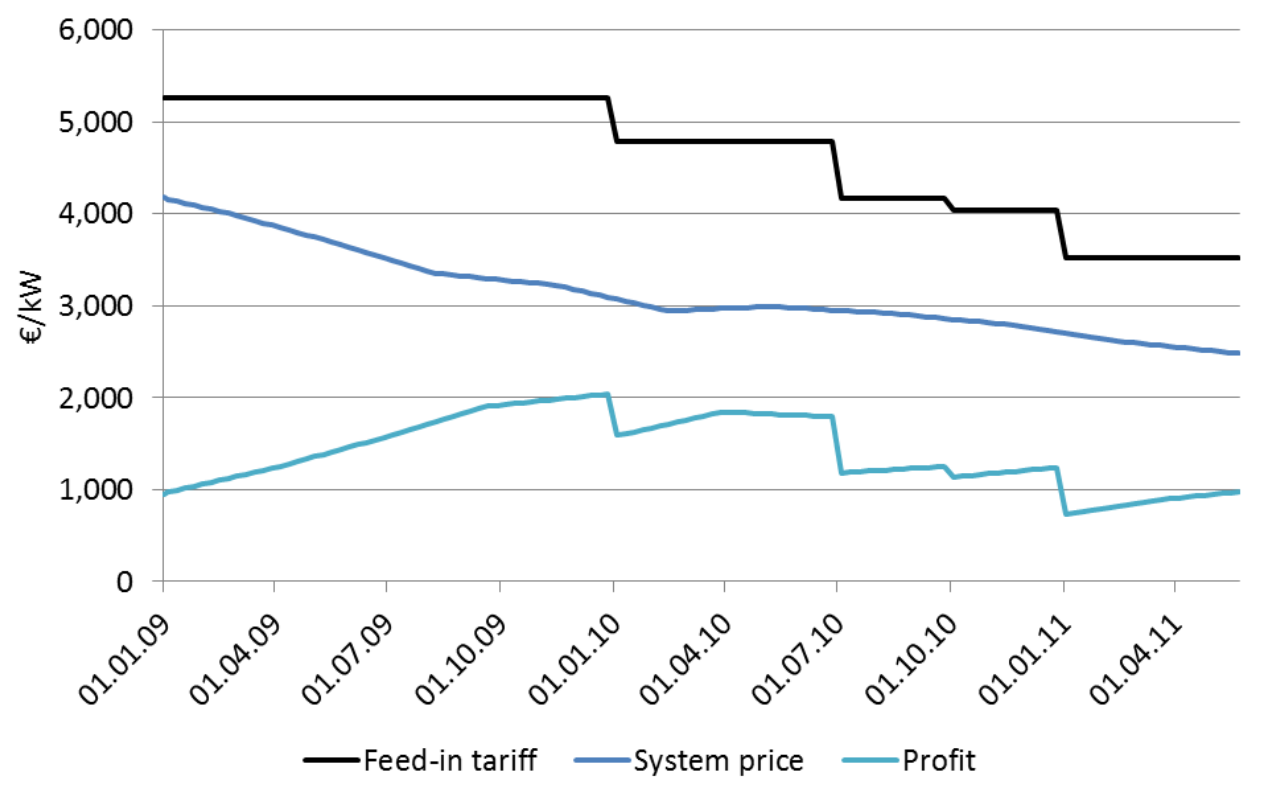

\footnotetext{
${ }^{3}$ www.pvlegal.eu

${ }^{4}$ System prices of Q2 2011 are assumed to stay constant within the last two weeks of May 2011.
} 
The evolution of profits, as well as system prices and present values of feed-in tariffs, is shown in Figure 4.1.

To test our first two hypotheses (see section 3), we analyze the relationship between PV installations and profits in the following. Figure 4.2 shows that the amount of weekly installations increases with rising profits for each year. However, we observe several outliers, which represent "clearance sale" effects in weeks before the feed-in tariff was reduced. Figure 4.2 also illustrates that the relationship between installations and profits has shifted over time, as in later time periods less profitability is needed for the same amount of installations. This seems to be the result of a maturing market with increasing experience and decreasing risk for project developers. These observations validate our first two hypotheses.

In our analytic framework we assume a linear correlation between weekly installations and profits in Germany. By adjusting for maturing market conditions in each year, we estimate the parameters $\alpha_{1}=0.0644$ and $c_{1}=68.586$ for 2009, $\alpha_{2}=0.0466$ and $c_{2}=18.906$ for 2010 , as well as $\alpha_{3}=0.1192$ and $c_{3}=83.737$ for 2011 . Although this trend might continue in the future, we assume that the relationship between weekly installations and project profitability in 2011 will stay constant in later periods.

Based on these parameters, Figure 4.2 shows the resulting evolution of PV installations (according to our basic model, see section 3.1).

Figure 4.2: Evolution of historic and model-based weekly PV installations (basic model) for systems $\leq$ $30 \mathrm{~kW}$

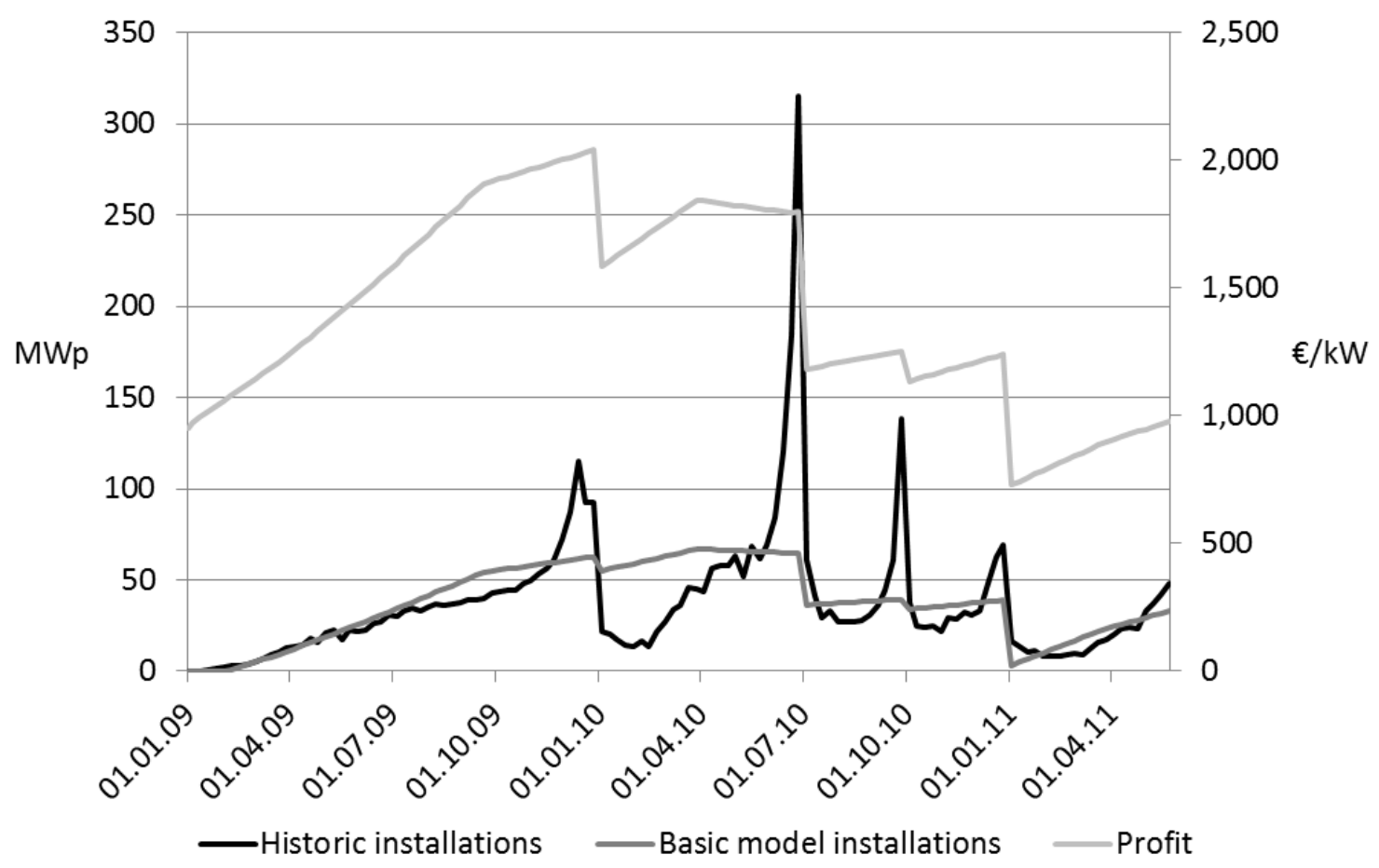


The basic model delivers a relatively realistic match of model-based and historic installations. However, the largest deviation to historic PV deployment are the demand peaks observed in periods before feedin tariff reductions. To simulate these peaks, we use our advanced model (see section 3.2).

As mentioned above, the overall process duration of PV projects in Germany varies between 3 to 8 weeks ( 6 weeks on average) for small-scale installations on residential buildings. So far we used the average project duration of 6 weeks to calculate profits of roof-top systems $\leq 30 \mathrm{~kW}$. However, project developers have an interest in accelerating the implementation process in periods prior to feed-in tariff reductions. Therefore projects which are started 3 to 5 weeks before a feed-in tariff reduction are implemented more rapidly, so as to be completed in the last week before the tariff cut. In the next sections, we will use this advanced model to simulate PV deployment between January 2009 and February 2012 for different feed-in tariff designs and system price scenarios.

\subsection{Model results for the current adjustment mechanism}

In this section, we use our advanced model (see section 3.2) to simulate weekly PV deployment between January 2009 and February 2012 based on the current PV feed-in tariff adjustment mechanism implemented in 2011 (as described in section 2.2). In our calculations of the feed-in tariff levels from January 2011 onwards we use rooftop systems $\leq 30 \mathrm{~kW}$ as representative category. The feed-in tariff adjustment is formulated based on total deployment volume. We integrate this in the model by assuming that the market share of projects $\leq 30 \mathrm{~kW}$ stays constant (35\% market share in 2010). To simulate PV installations from June 2011 onwards, we use observed system price declines between Q2 and Q4 2011 according to quarterly data from BSW-Solar (2011) and BSW-Solar Preisindex Photovoltaik (2012), and assume a further decline by 14\% between Q4 2011 and Q2 2012 (equal to price decrease Q2-Q4 2011).

In comparison to the basic model, the advanced model is able to simulate PV deployment with its characteristic demand peaks. Figure 4.3 shows that historic and model-based PV installations match fairly well. 
Figure 4.3: Evolution of historic and model-based weekly PV installations (advanced model) for systems $\leq 30 \mathrm{~kW}$

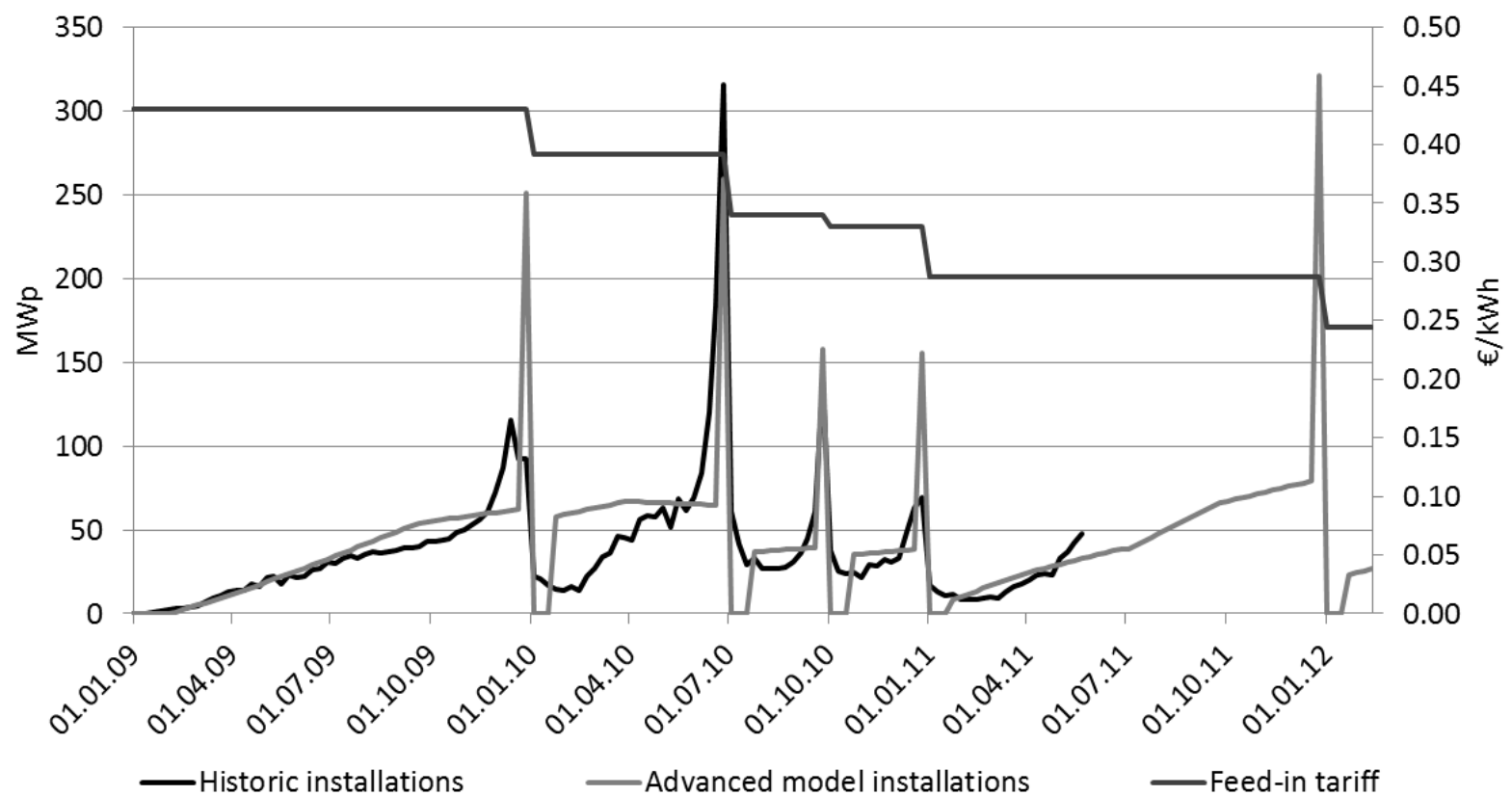

There was no feed-in tariff reduction on 1 July (and 1 September) 2011, as less than 875 MW of PV systems were registered at the Federal Network Agency between March and May 2011.

When comparing historic and model-based deployment, we observe that historic demand peaks are higher in summer 2010 and lower at the end of each year. These seasonal peak variations can be explained by (i) weather conditions (snow) at the end of December being more difficult concerning project project implementation, and (ii) lower demand at the end of the years due to the Christmas holidays.

\subsection{Model results for alternative design options}

The option to adjust the PV support level in response to ongoing deployment volumes has in principle been positively received by all stakeholders. During political discussions in 2011, two alternative options for the precise design of the adjustment mechanisms were brought forward by different political parties. These are in turn discussed based on the advanced model calibrated in section 4.1, so as to explore the implications of different design choices.

We consider the following alternative designs of the PV feed-in tariff:

\section{(1) Green design}

In February 2011, The Green Party suggested the following PV feed-in tariff design:

- Advanced tariff reduction to be divided into 4 dates, as shown in Table 4.1. Remaining reductions to be passed on to the following dates. 
- On 1 January 2012, the degression rate is to be calculated corresponding to the mechanism in the current adjustment design.

Table 4.1: Advanced feed-in tariff reductions in 2011 proposed by the Greens

\begin{tabular}{|l|l|l|}
\hline Reduction date & Qualifying period & Degression \\
\hline 1 May & February, March & $0 \%-3.75 \%$ \\
\hline 1 July & April, May & $0 \%-3.75 \%$ \\
\hline 1 September & June, July & $0 \%-3.75 \%$ \\
\hline 1 November & August, September & $0 \%-3.75 \%$ \\
\hline
\end{tabular}

\section{(2) Red design}

In December 2010, the Social Democratic Party suggested the following PV feed-in tariff design:

- Feed-in tariff to be reduced by 4\% every three months starting on 1 April 2011.

- On 1 January 2012, the degression rate will therefore also be $4 \%$.

To compare the green and red feed-in tariff designs to the adjustment mechanism currently in place, we will refer to the current mechanism as the "black design" in the following. Figure 4.4 shows the evolution of PV installations $\leq 30 \mathrm{~kW}$ for all feed-in tariff design options in the period January $2009-$ February 2012.

While the red feed-in tariff design includes fixed $4 \%$ reductions every three months, feed-in tariff cuts in the black and green designs depend on the amount of PV capacity installed in the previous months, and thereby differ in the respective system price scenarios. Similar to the $0 \%$ degression in July 2011 for the black design, the green design results in 0\% degression rates for 1 May and 1 July 2011, since in the respective qualifying periods on a yearly projected basis less than $3.5 \mathrm{GW}$ solar systems have been installed. The degression rates for 1 September 2011, 1 November 2011 and 1 January 2012 amount to $6.75 \%, 8.25 \%$ and $0.65 \%$ respectively for the green proposal. 
Figure 4.4: Evolution of feed-in tariffs and weekly installations $\leq 30 \mathrm{~kW}$ for different adjustment designs

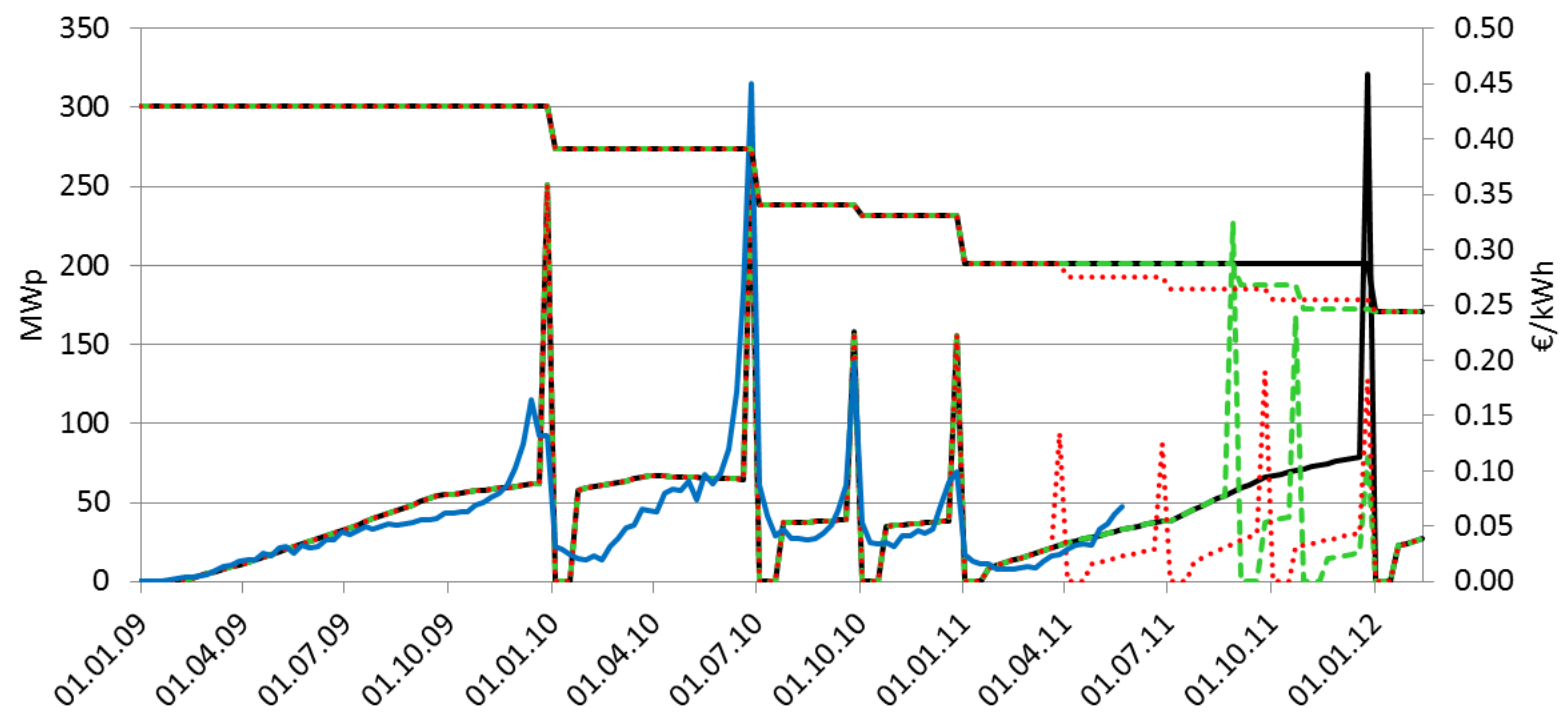

$$
\begin{array}{llll}
\text { Black installations } & ---- \text { Green installations } & \cdots \cdots . . . & \text { Red installations }
\end{array} \text { Historic installations }
$$

However, the future price development is not known at the time of decisions on the adjustment mechanism. Therefore, the designs need to be tested against different potential scenarios. The evolution of system prices from Q4 2011 onwards is difficult to predict, especially because of the following characteristics of the global price for PV modules:

- There are global production capacities for around $50 \mathrm{GW}$ new PV modules ${ }^{5}$, which have been operated with low utilization factors often already over the last years.

- Demand for PV modules depends on the evolution of feed-in tariffs in many countries, and is difficult to predict.

We use the following scenarios for the future evolution of PV system prices in Germany:

Scenario 1 (S1): As defined in section 4.2.

Scenario 2 (S2): The price continuously declines from June 2011 onwards by yearly $17 \%$ (average within last three years).

Scenario 3 (S3): The price declines from June 2011 onwards by 10\% each quarter (equal to the maximum quarterly price decrease in Figure 2.1).

Table 4.2 summarizes model-based feed-in tariff reductions in the three system price scenarios. While the black design leads to a 15\% feed-in tariff reduction at the beginning of 2012 for all system price

\footnotetext{
${ }^{5}$ According to Sarasin (2011), there are $21 \mathrm{GW}$ of demand and around $50 \mathrm{GW}$ of production capacity for solar modules at the end of 2011.
} 
scenarios, the green design would result in advanced $6.75 \%$ and $6.60 \%$ cuts on 1 September and 1 November 2011 respectively in scenario 2. As scenarios 1 and 3 contain larger system price reductions, they result in higher degression rates on 1 November 2011 for the green design.

Table 4.2: Feed-in tariff degression rates in different system price scenarios

\begin{tabular}{|l|c|c|c|c|}
\hline $\begin{array}{l}\text { Date of feed-in } \\
\text { tariff reduction }\end{array}$ & $\begin{array}{c}\text { Feed-in tariff } \\
\text { design }\end{array}$ & Scenario 1 & Scenario 2 & Scenario 3 \\
\hline 1 Sep. 2011 & Green & $6.75 \%$ & $6.75 \%$ & $6.75 \%$ \\
\hline 1 Nov. 2011 & Green & $8.25 \%$ & $6.60 \%$ & $8.25 \%$ \\
\hline 1 Jan. 2012 & Black & $15.00 \%$ & $15.00 \%$ & $15.00 \%$ \\
\hline 1 Jan. 2012 & Green & $0.65 \%$ & $2.41 \%$ & $0.65 \%$ \\
\hline
\end{tabular}

The red design results in the lowest feed-in tariff levels in 2012, as shown in Table 4.3. When comparing feed-in tariff levels at the beginning of 2011 and 2012, the red design shows a yearly feed-in tariff reduction of $15.1 \%$.

Table 4.3: Feed-in tariff levels for systems $\leq \mathbf{3 0} \mathrm{kW}$ for different designs options and price scenarios

\begin{tabular}{|l|c|c|c|c|}
\hline $\begin{array}{l}\text { Feed-in tariff } \\
\text { design }\end{array}$ & Black & \multicolumn{2}{|c|}{ Green } & Red \\
\hline Scenario & S1 \& S2 \& S3 & S2 & S1 \& S3 & S1 \& S2 \& S3 \\
\hline $\begin{array}{l}\text { December 2011 } \\
\text { [€/kWh] }\end{array}$ & 0.2874 & 0.2503 & 0.2459 & 0.2543 \\
\hline $\begin{array}{l}\text { January 2012 } \\
{[€ / \text { kWh] }}\end{array}$ & 0.2443 & 0.2443 & 0.2443 & 0.2441 \\
\hline
\end{tabular}

For the current feed-in tariff adjustment mechanism, the analytic model projects $2.5 \mathrm{GW}$ deployment for installations $\leq 30 \mathrm{~kW}$ for 2011 in scenario 1 (based on recent system price data). If we assume that they continue to constitute $35 \%$ of the market (as in 2010), then this would correspond to $7 \mathrm{GW}$ total deployment volume in 2011. This is similar to the first indications of 2011 deployment of $7.5 \mathrm{GW}$ (according to Bundesnetzagentur).

Table 4.4: PV installations in 2011 [GWp] for different feed-in tariff designs and price scenarios

\begin{tabular}{|l|c|c|c|c|c|c|c|c|c|}
\hline Feed-in tariff design & \multicolumn{3}{|c|}{ Black } & \multicolumn{3}{c|}{ Green } & \multicolumn{3}{c|}{ Red } \\
\hline Scenario & S1 & S2 & S3 & S1 & S2 & S3 & S1 & S2 & S3 \\
\hline$\leq 30$ kW category & 2.5 & 2.1 & 2.6 & 1.7 & 1.4 & 1.8 & 1.3 & 0.9 & 1.4 \\
\hline
\end{tabular}

Table 4.4 shows that the black feed-in tariff design results in the highest amount of PV installations, in comparison to the alternative design options. This is because the feed-in tariff is only reduced in January 2012 for the black design, while the first advanced green reduction occurs in September 2011, and feed- 
in tariff cuts are already implemented within the red design in April and July 2011. Due to its early adjustment steps, the red design leads to lowest installations in all system price scenarios in 2011.

Mitchell et al. (2011) define policy effectiveness as "the extent to which intended objectives are met, for instance the actual increase in the amount of RE electricity generated or share of RE in total energy supply within a specified time period". Therefore, we compare the effectiveness of the different PV feed-in tariff design options as "the extent to which the annual $3.5 \mathrm{GW}$ installation target is met".

Based on our price scenarios, the red feed-in tariff design is most effective in reaching the German annual PV installation target of $3.5 \mathrm{GW}$. In price scenario 1, it leads to $1.3 \mathrm{GW}$ in 2011 for systems $\leq 30$ $\mathrm{kW}$. Assuming that these installations continue to constitute $35 \%$ of the market (as in 2010), this implies a 3\% overshoot above the target. According to this approximation, in price scenarios 2 and 3 the deployment volume would deviate from the target by $-26 \%$ and $+17 \%$ respectively. However, this is due to the fact that system prices reductions and fixed feed-in tariff cuts arerelatively well matched. As the red design includes constant feed-in tariff cuts, the targeted market growth corridor can only be reached if system prices constantly decrease by around $15 \%$ each year. If price decreases had been significantly weaker or stronger, the deployment target would not have been as closely reached. While this design option provides predictable investment security, it faces the challenge of realistically predicting system price reductions for the future.

Within the scenarios assessed, the black feed-in tariff design is the least effective in reaching the German installation target. Assuming that installations $\leq 30 \mathrm{~kW}$ continue to constitute $35 \%$ of total deployment, it overshoots above the target level between $+71 \%$ (S2) and $+115 \%$ (S3). Using the same methodology, the green design delivers deployment volumes closer to the target level, with deviations ranging between $+12 \%$ and $+50 \%$.

Due to their modular structure, PV panels can be installed a lot quicker than e.g. wind turbines. With PV project durations ranging between three and eight weeks for small-scale systems on residential buildings, and six to 24 weeks for small to medium-scale installations on commercial buildings, the black feed-in tariff design is not able to adjust quickly enough to compensate for rapidly changing system prices. Due to its more frequent adjustment mechanism, the green design would follow these price evolutions more closely and thereby match deployment target levels more effectively.

\section{Conclusion}

This paper reviews the experience with the adjustments of the photovoltaics feed-in tariff scheme in Germany. The National Renewable Energy Action Plan of the German government targets the installation of 52 GW of PV power generation capacity in Germany by 2020, with annual targets of 3.5 GW. However, in both 2010 and 2011 yearly PV deployment was around 7.5 GW.

This shows that setting appropriate levels for feed-in tariffs has been a challenge in recent years, especially as PV system prices decreased faster than expected since 2009. The feed-in tariff for new installations was adjusted thereafter by several short-term political interventions. Despite the 
differences between these individual adjustments, the market responded in a similar manner in all cases. In periods prior to feed-in tariff reductions, the numbers of installations peaked as investors aimed to still qualify for the higher tariff level. In this regard, larger projects are usually more responsive to changing support schemes. However, as small-scale PV installations $\leq 30 \mathrm{~kW}$ account for a large share of total installations in Germany, this work focuses on the small-scale roof-top category of the German PV feed-in tariff.

The analytic model introduced in this paper is able to simulate the evolution of new PV installations and feed-in tariffs on the basis of observed PV system prices. This simple model is based on only three factors: (i) deployment increases proportionately with project profitability, (ii) profit expectations of investors decrease every year, and (iii) in periods before feed-in tariff reductions, projects are implemented faster in order to still qualify for the higher tariff.

Model results show that demand responds very quickly (as project duration of small-scale PV systems is only six weeks on average) to declining system prices. The larger profitability leads to increasing installation numbers. The demand peaks result from accelerated projects which are completed in the last week before a feed-in tariff reduction. The simulated numbers closely match the observed weekly deployment numbers. Therefore we assume that we have identified the main factors driving the deployment choices. We cannot exclude that in the future or for other project sizes, investors also respond to other factors reducing or increasing the deployment numbers, like uncertainty of policy development or a mobilizing effect if there is a perception of a last opportunity to qualify for support.

In the model results and in the available historic data, the majority of new systems is already installed within the weeks before a demand peak - deployment already increases significantly more than one month in advance. Hence, the necessary information and responsiveness exist as prerequisites for a prompt adjustment of the feed-in tariff level.

In the course of political discussions in 2011, three options for the precise design of the adjustment mechanism were brought forward by different political parties. The model is used to analyze these policy design options in different PV system price scenarios. Simulation results show that: (i) the feed-in tariff adjustment mechanism implemented in 2011 is not effective in reaching the German annual installations target; (ii) constant tariff reductions on a quarterly basis would have better matched target levels in 2011, but face the challenge of predicting future price reductions; (iii) a flexible adjustment mechanism with more frequent tariff reductions would reach target levels most effectively.

The experience of the last years shows that demand behaves according to simple rules. Based on these rules, individual feed-in tariff adjustment proposals can be tested to identify mechanisms that are robust to different PV system price developments. Moreover, the adjustment frequency of the feed-in tariff has to be increased to better correspond to the short project durations of small-scale systems. 


\section{References}

Bundesministerium für Umwelt, Naturschutz und Reaktorsicherheit. 2011. Zeitreihen zur Entwicklung der erneuerbaren Energien in Deutschland.

Bundesnetzagentur. 2012. Zubau an Photovoltaik-Anlagen 2011 noch höher als im Rekordjahr 2010 (Pressemitteilung 9 January 2012).

Bundesrepublik Deutschland. 2010. Nationaler Aktionsplan für erneuerbare Energie gemäß der Richtlinie 2009/28/EG zur Förderung der Nutzung von Energie aus erneuerbaren Quellen.

Bundesverband Solarwirtschaft e.V. (BSW-Solar). October 2011. Statistische Zahlen der deutschen Solarstrombranche (Photovoltaik).

Bundesverband Solarwirtschaft e.V. (BSW-Solar). Preisindex Photovoltaik. www.solarwirtschaft.de/preisindex (18.1.2012)

Änderungsantrag zum "Entwurf eines Gesetzes zur Umsetzung der Richtlinie 2009/28/EG zur Förderung der Nutzung von Energie aus erneuerbaren Quellen" (Europarechtsanpassungsgesetz Erneuerbare Energien - EAG EE). February 2011. Available at: http://www.erneuerbareenergien.de/inhalt/46976/4590.

Reichmuth, Matthias. Vorbereitung und Begleitung der Erstellung des Erfahrungsberichtes 2011 gemäß $\S 65$ EEG, Vorhaben II c Solare Strahlungsenergie. Endbericht. Leipziger Institut für Energie GmbH, 1. Juni 2011.

Erneuerbare-Energien-Gesetz vom 25. Oktober 2008 (BGBI. I S. 2074), das durch Artikel 2 Absatz 69 des Gesetzes vom 22. Dezember 2011 (BGBI. I S. 3044) geändert worden ist.

Mitchell, C., J. Sawin, G. R. Pokharel, D. Kammen, Z. Wang, S. Fifita, M. Jaccard, O. Langniss, H. Lucas, A. Nadai, R. Trujillo Blanco, E. Usher, A. Verbruggen, R. Wüstenhagen, K. Yamaguchi. 2011. Policy, Financing and Implementation. In IPCC Special Report on Renewable Energy Sources and Climate Change Mitigation [O. Edenhofer, R. Pichs-Madruga, Y. Sokona, K. Seyboth, P. Matschoss, S. Kadner, T. Zwickel, P. Eickemeier, G. Hansen, S. Schlömer, C. von Stechow (eds)], Cambridge University Press, Cambridge, United Kingdom and New York, NY, USA.

Photon. Solarstrom-Magazine 2/2010, 9/2010, 4/2011, 8/2011.

PV LEGAL project: www.pvlegal.eu

REN21. 2011. Renewables 2011 Global Status Report (Paris: REN21 Secretariat).

Sarasin (2011). Solarwirtschaft: Hartes Marktumfeld - Kampf um die Spitzenplätze.

http://www.sarasin.de/internet/iede/index_iede/about_us_news_iede?reference $=132335$ \&checkSum= 7B7A26E8159E6446C9EEBB881A2A5BB5 (retrieved 24 January 2012) 